\title{
Textual Analysis of Directive Speech Acts on "Andung" Existence as Oral and Original Traditional Culture and Literature of Tobanese (A Case Study on Tobane relatives of Distric of Dolok Sanggul, Humbang Hasundutan Regency)
}

\author{
Jubilezer Sihite \\ : ezerjubil123@yahoo.com
}

\begin{abstract}
Textual Analysis of Directive Speech Acts Found on "Andung" Existence as Oral and Original Traditional Culture and Literature of Tobanse is explained. The study is aimed to find out the phenomenon and textual (contour, melody, style) of directive speech acts of Andung by the relatives of Tobanese including during mourning ceremony. It is a kind of lamentation art usually expressed during a ceremony. It is also a combination among crying, speaking and singing in sorrow. Andung itself will be more dramatic because it is usually expressed repeatedly. But not everyone is accustomed and skilled in it. Some people argue, this expression of sadness is not something that is learned. It is a psychological innate of a person who has a sensitive heart and is supported by the expressive nature he/she has. The source of the data is three videos of ceremony provided that contain sadness of mourning ceremony. The data is all the utterances that expressed by the relatives during the ceremony being running on. Having conducted an analysis, it is found that according to the melody there are five ways of expressing Andung art, they are : repetitive, interative, reverting, stropic and progressive. According to the contours, it is found that there are five form of Andung art, they are : ascending, descending, pendulous, terraced and static. Andung art is only the sound of crying coming out without it accompanied by music/musician. It is expressed as a feeling overflow; Grief, death of a loved one or relative, lament, singing, poetry and pray. Some kinds of expressive speech acts were uttered by the relatives. They are apologizing, thanking, condoling, congratulating, complaining, lamenting, protesting, deploring, boasting, complimenting, greeting, and welcoming. The most dominantly expressed is complaining. Because the relatives complained about how suddenly something bad and sorrow happening to them or family. The representation of cultural values in the Andung art tradition are to show respect, health, honesty, politeness and kinship.
\end{abstract}

Keywords : Andung, local tradition, lamentation, directive speech acts, mourning ceremony 


\section{Background}

Language is a world view to understand life and human beings themselves. Wilhelm von Humbold (in Wierzbicka, 2010: 4) said "there is a characteristic in the world-view, every language contains the whole conceptual fabric and mode of presentation of a portion of mankind." The Toba Batak community also use the Toba Batak language to describe the reality of his world or life; there are three variations of the Toba Batak language, namely ordinary language (general), polite language, and lament orAndung - andung (AA).

Language is commonly used when talking about general matters, talking to other people. Polite language is used when speaking, telling a friend or an older person to show respect, while the AA which is expressed by the people in a sad melody that looks like a poem, dedicated to the death of a loved one. The choice of AA language is very different from the use of general language or polite language so that not everyone is able to express it even though it comes from ethnic of Toba Batak society. According to Sibarani (2012: 123), AA of Toba Batak ethnic sadness include oral tradition because it is a traditional cultural activity inherited from generation to generation in the form of verbal (verbal) wording, containing cultural values as local wisdom, and community shared property certain. Local wisdom can be a function as a living guide for the ethnic of Toba Batak community. AA contains advice for the younger generation to love and respect parents, while parents must have a sense of responsibility towards their wives and children. AA also contains the value of trust in God Almighty so that people always pray for His blessings and forgiveness. AA is like rhythmic rhymes sung in the presence of mourners when there is death, sadness and disaster with the expression of beautiful and subtle, poetic language with aesthetically humanist.

A different name from each kind of the deathfor the people of Toba Batak describes the reality of the life experience itself. Therefore, AA language as a medium for expressing sadness becomes a concise picture of the life journey expeorienced and clearly illustrated in his choice of words (Wierzbicka, $2010: 4$ ). Equivalence is a key word in determining whether a text can be categorized as a translation or not. "Can that equivalence be fully achieved?" Is a question that continues to reverberate. The answer to this question is certainly "no" because in every translation and translating activity, the translator is confrontedin two texts that are linguistically and culturally different (Nida \& Taber, 1969; Larson, 1984; Simatupang, 1993). However, translation is possible if we think that the same concept, meaning or message can be expressed in different ways.

According to Nida, what can be expressed in a language can also be expressed in other languages because language is generally different in matters concerning perception, while in matters relating to the concept of language have the characteristics of universality (Nida \& Taber 1969: 21).AA contains the philosophy 
of life and the Toba Batak collective awareness that can direct the way of life and the way of thinking of its members based on the customs that theyfirmly held and applied. Unfortunately, now the symptoms indicate the threat of extinction of the AA tradition. The younger generation of Toba Batak society no longer understandthe sad AA that contain teaching values inherited from their predecessors. In fact, the Toba Batak community who live in the village even though they rarely practice AA, they are strongly influenced by technological progress and even in daily communication they often use Indonesian. The fact that the use of AA is almost extinct and the desire to preserve, document and translate it into Indonesian. To preserve the cultural values and philosophy of life contained in AA itself, it is deemed necessary to obtain,interpreted(Foley $1997:$ 3)and translated idiomatically (Larson, $1984: 3$ ) into Indonesian so that the ethnic Toba Batak community especially the younger generationunderstand it and preserve the local wisdom contained in it.

Speech act is an utterance that serves a function in communication. A speech act might contain just one word, as in "Sorry!" to perform an apology, or several words or sentences: "I'm sorry I forgot your birthday. I just let it slip my mind." Every speech act can be distinguished by three things (Austin, 1962:14): Firstly, the utterances can be called the locutionary act.Locutionary speech act is what is said' the form of uttered; the act of saying something, for example: If someone says 'Knock the door!' the locutionary act is the realization of the speaker's utterance. Secondly, speaker's intention toward hearer's is called the illocutionary act, for example: The utterance "I swear to give it back next time" is used to perform the speech act of promising. Last, the message that the hearersget, his interpretation of what the speaker says, is the perlocutionary act, for example: The utterance " there is something in your shoulder! " may cause the listener to get panic and to look on his shoulder.

The reason why the writer uses expressive speech act, because the expressive speech act carried out by a speaker meaning of an utterance is the act viewed in term of the utterance's significance within a conventional system of social interaction. An speech act refers to type of function the speaker intends to fulfill, or the type of action the speaker intends to accomplish in the course of producing utterance.

In this research, the writer only focuses on the expressive speech acts point. It is the characteristic that emphasizes of each type of speech act. For instance, the characteristic that emphasizes an assertion is to describe how things are; the characteristic point of a promise is to commit one self to a future course of action. In this research, the writerobserves the use of directive attempted by the speakers during mourning ceremony, for example : asking, commanding, requesting, ordering, forbidding, advising, suggesting. Asking is the call for an answer to or about (ask her about it, ask him his name, just asking). Commanding is to be direct with the authority, (give order to). Requesting is the act of asking for something (came at his request. It is not assertion). Ordering gives an authoritative direction or instruction to 
do something. Forbidding is to tell (someone) not to do something. Advising is to give (someone) a recommendation about what should be done. Suggesting is to offer for consideration or action, propose (suggest things for someone to do). The identification of the problems are ;some of expressions consisiting of directive speect act, the meaning of speech acts involved are rarely revealed, many people do not get the hidden message the expression of AAand people need to know the meaning in order to make it clear.

\section{Methodology Research}

The design of this research was a descriptive qualitative. The data were described systematically to get an accurate and factual result. In this research, the writer identified and described the kinds of directive speech acts which occured in the utterances by the time lamenatation are expressed. The purpose of descriptive research was "to describe systematically the facts and characteristics of a given population or area of interest, factually, and accurately" (Isaac and Michael, 1981:46). One of the characteristics of descriptive research was that it was used in the literal sense of describing situations or events. The data analysis in this research used qualitative data analysis. Qualitative data analysis means that "all data that are analyzed in the form of utterances and words, not in the form of number" (Wilkinson, 2000:7). Andung-andung (AA) as an art of Toba Batak culture was considered as the focus of this research. The unit of analysis of this research was in the form of utterances found in the expression of AA by the relatives of Toba Batak society. The source of data in this research was taken from all the AA expressed by all the realtives during themourning ceremony. The writer will display the text the AA presented from three mourning ceremonies had been analyzed, they are : mourning ceremony of P. Sormin/M.Sihite (PS) in April 2012, the second is S.Purba/M. Sihite (SP) in October 2015, and the third J. Purba/M.Sihite (JP) in December 2018. The method used in preparing the data related to the subject of this research was documentation method because the writer used the video and scripts to collect the data. Nawawi (1991: 95) states that the documentation method was "a method of collecting data conducted by classifying the written materials related to the problem of the study used for obtaining the data by some variables such as magazines and books as the data". The necessary steps of collecting the data are reading the news more than once, collecting all the utterances taken, tabulating all the data into a table, finding out all the words, sentences,phrases, utterances having directive speech acts as the data and noting down the data based on their classification.

\section{Finding And Discussion}

The display of the data was done formerly by giving the description of direct speech acts uttered by the Tobanese relatives during mourning ceremony in Toba Batakculture. The finding utterances and grouping types of expressive speech acts in utterances that can help the readers to understand what will be provided by the 
writer.All the data is taken from utterances that expressed by the relatives of Tobanese during mourning ceremony. The following are examples of utterances in AA by the Tobanese :

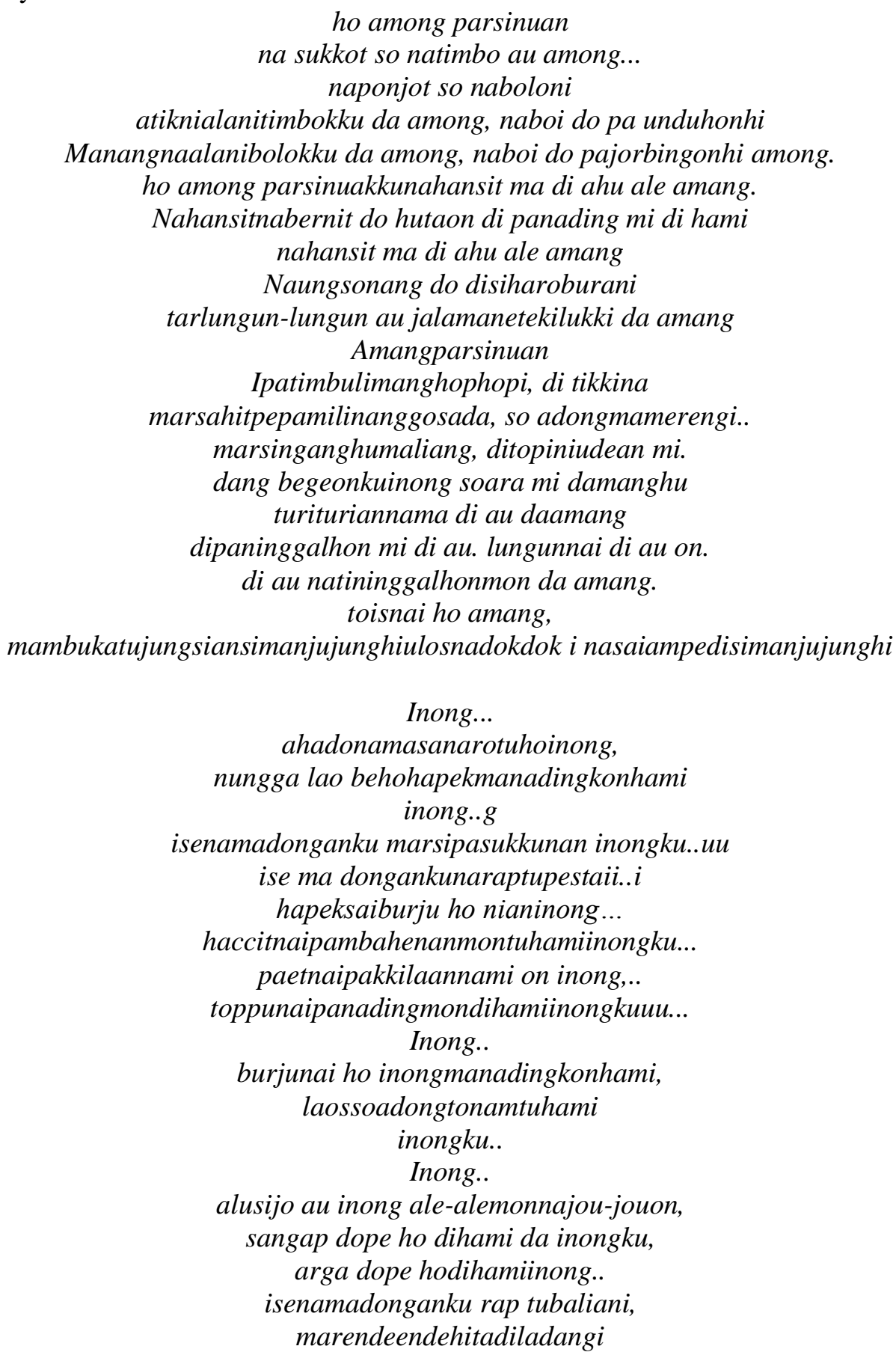


agetahetung so tagam dorohakkudiparlaomoninongku..

naboha do di hilala ho inong..umbaentoppuparlaomoninongku.. alusijo au inonggg..

naung boha na ma nasib ni bapa ta i ito.

halaklahomarnatal,ianggo au lao do tuhudean mi. dohotanakdohotboru ta on, saitumatangis. amangsiadopan...

marsirang ma hitahape, sinirangnihamateani

tinggal ma hamihape, dohotrindangnisiubeonta on, na lima on ...

putusnirohamiamang ... pasombuhamindangmaramai

tuise ma hamimangalu-alu ...

ai so adong be ho amangnaburju ...

tudianamarindangnisiubeontana lima simardung on ... dangolnai di hami da among,

tuise ma hamipaboahonsitaonontanadokdok on

manghuntisisiknisilangkopon ma hapesiboruadi da among ...

sitaononnadokdoki, parsumalimanina so adongtudosan ni $i$... marsijugukon ma ho amang,

asamarturiak nisiubeontana lima simardungi... hitaraphon angkarindang

tolu ma sinuantunasta, duasinuanbeuntai ...

Imasudeianakkontainahansit di pudian mi... asi ma rohaniTuhanta $I$,

sai dilehon ma hahipason di hamidohotianakkontaitujoloanniari on sai anggiat ma dijangkonTuhanta ho tulambung $\mathrm{Na}$...

boi do hitapajumpang muse di ariparpudii... selamatjalan ma di ho selamattinggal ma di hami... bapa...yamangtahe... ndangtarlupahonahusude..podamituahu Bapakku... и...и..u...marhua do ro ho lompaparidianhu..niтти...

hulompa do... oo..oo.. malojahu ho... hu siampudani...HP mi dilean ho do.

Having analyzed all the data, it is found that the amount of the frequencies there are 138 utterances that contain expressive speect acts during the mourning ceremony. And the most dominantly uttered of all is complaining. It means that all the relatives of the family expressed discontent. The preparatory condition is that what one is expressing discontent about is bad, though this need not strictly be a presupposition since one can complain simply by saying that it is bad. There is no preparatory condition that the hearer must be in any way responsible for what one is complaining 
about. One can complain about the weather, inflation, or etc. This is why complaining can be either an assertive or an expressive. One can complain by asserting that something is bad or one can simply express one's discontent. From the text above is a picture of the sad story of the doer. AA is not accompanied by music. The person who did the sama AAwereall the relatives of the person who died. The doerof AA revealed what they felt while crying or feeling very sad, the people who heard it also were sad even there too who cried related to the time his life was the siblings, wife, son, daughter or friend of him who are the most familiar with, when they were walking or partying with them always in the past.

AA usually expressed with melody. A melody is a line or arrangement of elements of a tone that is combined with rhythmic elements and moves/runs in time. Naturally the two elements are not can be separated. Melodies are composed of a series of tones horizontally. From the melody and countours poin of view, the writer also found that all the utterances ware expressed in several types of melody, they are :repetitive is a form of repetitive singing, interative is the form of singing that uses a small melody formula with the tendency of repetitions in the whole song, reverting is the form of singing that occurs in the repetition of the first phrase after melodic deviation occurs, stropic is the form of singing whose repetition of the melody remains the same but the text new song, progressive is the form of singing that continues to change using material new melody. If it is related to the previous observation, then the form of singing AA can be referred to as a repetitive form that is the form of singing repeated.

Contours are lines or grooves of melodies in a song, according to Malm (1964: 8) can be divided into several types, namely:ascending which is a melodic line that goes up from a low tone to a tone tall one, descending is a melodic line that has a lower tone than the higher one lower tone, pendulous is a melodic line that is curved from a low tone to higher tone, then back to a lower tone or vice versa from higher tones to lower tones and back to more tones high, terraced which is a melodic line that is jangling like a step from a tone the lower one to the higher note, then moves parallel, then moves to a higher tone and so on which eventually shaped like a child stairs, static that is the melody line whose nature is still moving within its scope limited/flat.Based on the explanation above, the writer can see a contour of melodies fromsinging AA is pendulous. This can be seen from the journey of the melody of the tonehigh to low tone then back to high note and vice versa.

\section{Conclusions And Suggestions}

The AA as oral tradition at the mourning ceremony of the Toba Bataksociety (study of oral traditions) can be concluded as follows: (1) According to melody of songs:repetitive(form of repetitive singing), interative (form of singing that 
uses a small melody formula with the tendency of repetitions in the whole song), reverting (the form of singing that occurs in the repetition of the first phrase after melodic deviation occurs), stropic (the form of singing whose repetition of the melody remains the same but the text new song), progressive (the form of singing that continues to change using material new melody). (2) According to contours : ascending (a melodic line that goes up from a low tone to a tone tall one), descending (a melodic line that has a lower tone than the higher one lower tone), pendulous (a melodic line that is curved from a low tone to higher tone, then back to a lower tone or vice versa from higher tones to lower tones and back to more tones high), terraced (a melodic line that is jangling like a step from a tone the lower one to the higher note, then moves parallel, then moves to a higher tone and so on which eventually shaped like a child stairs), static (the melody line whose nature is still moving within its scope limited / flat.) (3) AA is only the sound of crying coming out without it accompanied by music/musician. The contents of the poem are usually about the events that happened to him when the event took place. AA is expressed as a feeling overflow; Grief, death of a loved one or relative, lament, singing, poetry. The cultivation of text from AA can be said spontaneously, even though it is actually based on patterns that already exist in the community. AA is a lament, the cry of crying or the hum of heart that is strung in poetry spontaneous literature and song as expressions of deep feelings. (4) Some kinds of expressive speech acts were uttered by the relatives. They are apologizing, thanking, condoling, congratulating, complaining, lamenting, protesting, deploring, boasting, complimenting, greeting, and welcoming. And the most dominantly expressed is complaining. Because the relatives complained about how suddenly something bad and sorrow happening to them or family. (5) Representation of cultural values in theAA tradition are to show respect, health, honesty, politeness and kinship.

The tradition of AA as one of Toba Batak traditions which is almost extinct and very apprehensive as it should be as Toba Batak people, helped to maintain and to preserve this oral tradition as a strengthof Toba Batak identity. Therefore it is suggested that; (1) The tradition of AA as an oral tradition of Toba Batak is also considered as an art in the Toba Batak culture so that the tradition of AA can be used as performing arts. As an oral and artistic tradition, AA that contains these cultural values will still exist and survive in the midst of technological developments. If the government has agreed to incorporate into extracurricular activities or become local content in schools, especially on Toba Batak culture. Thus the tradition of AA will continue to exist and survive in the midst of today's globalization. (2) The government must provide targeted and planned policies in examining oral traditions so that more and more interested in examining regional oral traditions AAas a traditional song of lament of the Toba Batak community is one of them elements of the identity of the community, as well as in the intermediate interaction to be very opportunities are created towards consensus. (3) The AA in this paper is based solely on the prevalence that exists in the area of Batak Toba culture. The culture of the Toba Batak community which is still divided in some cultural areas, for the 
perfection of a study of the AA presumably it is also necessary to conduct a study in other Tobacultural areas. (4) Until now, books that can be used as reference material aboutToba arts, especially those related to folk songs are very difficult orthere hasn't even been found, for this it seems to researchers or writers and observers of art topay attention to it. The existence of the tradition of AA at the event of the death of the Toba Batak community was increasingly alarming. The speakers at the ceremony of the death of the community at the moment are very difficult to find. This AAtradition is considered no longer suitable for today. There are several factors that have resulted in shifts and changes in the AA tradition at this time are religion, education, language, culture, and economics. (5) For the basis of the study it should also be planned to make an art documentationscientific nature of the traditional songs of the Toba Batak communities. The documentationcan be in the form of video or audio-visual so that people will holdfield research based on that documentation.

\section{References}

Austin's Speech Act Theory and the Speech Situation Etsuko Oishi Esercizi Filosofici 1, 2006, pp. 1-14

Bach, K. and R. Harnish. 1979. Linguistic Communication and Speech Acts. Cambridge, Mass: MIT Press.

Pasaribu Ben . 2004. Pluralitas Musik Etnik. Medan : Pusat Dokumentasi dan Pengkajian Kebudayaan Batak Universitas HKBP Nomensen.

Bhientamie, Athien. 2015 Anlysis Speech Act of Directive Utterances in Sherlock Holmes"Scarlet" Novel. Muhammadiyah University of Surakarta Unpublisherd Research Paper.

Dewi (2012) analyzes Speech Act of Command by the Main Character in the Elizabeth: The Golden Age movie. . Muhammadiyah University of Surakarta. Unpublished Research Paper.

Foley, W.A. (1997): Anthropological Linguistics. Oxford:Blackwell.

Koesnosoebroto, B. 1988. The Anatomy of Prose Fiction. Jakarta: Depdikbud.

Larson, Mildred L. 1984. Translation: Theoryand practice, Tension and Interdependence. Philadelphia: John Benjamins publishing.

Larson, Mildred L. 1984. Meaning-Based Translation: A Guide to Cross Language Equivalence. America: University of America.

Levinson, S.C. 1983. Pragmatics. Cambridge : Cambridge. University Press.

Loss, Euegene E. 2004. Definition of Pragmatics. Retrievedon Oktober13, 2013 fromhttp://www.sil.org/whatispragmatics.htm

Moleong, Lexy J. 2006. Metodologi Penelitian Kualitatif. Bandung: PTRemaja Rodakarya.

Nadar, F. X. 2009. Pragmatik danPenelitian Pragmatik. Yogyakarta:GrahaIlmu.

Nida, Eugene A, \& Taber, Charles R. (1969). The Theory and Practice of Translation. UBS: Leiden. 
Searle, John. 1974.Speech Acts: An Essay in the Philosophy of Language. Cambridge: Cambridge University Press.

Searle, John. 1976. A Classification of Illocutionary Acts.Language in Society, Vol. 5, pp.1-23.

Sibarani, Robert. 2012. Kearifan Lokal : Hakikat, Peran dan Metode Tradisi Lisan. Jakarta. Asosiasi Tradisi Lisan (ATL)

Situmorang M. 1964. Arkeologi Budaya Indonesia, Pelacakan Hermeneutis - Historis Terhadap Artefak-Artefak Kebudayaan Indonesia. Yogyakarta: CV. Qalam

Vanderveken, Daniel. 1990. Meaning and Speech Acts vol 1 Principles of Language Use. Cambridge University Press, Cambridge.

Wierzbicka, A 1999, 'Language, Culture and Meaning: Cross-cultural linguistics', in Dirven, René; Verspoor, Marjolin (ed.), Cognitive Exploration of Language and Linguistics, John Benjamins Publishing Company, Amsterdam, pp. 137-159.

Wilhelm_von_Humboldt_and_John_Stuart_Mill_on_Bildung_and_Self-Development. 1971-1810 Journal of History of Ideas $441983: 55-73$.

Yule, George. 2006. The Study of Language (third edition). Cambridge: Cambridge University Press. 